\title{
Analisis Kesulitan Siswa dalam Pembelajaran Daring pada Materi Geometri Kelas VII SMP Kota Pekanbaru
}

\author{
Widya Shintya Dewi ${ }^{1}$, Maimunah ${ }^{2}$, Yenita Roza ${ }^{3}$ \\ ${ }^{1,2,3}$ Program Studi Magister Pendidikan Matematika, Universitas Riau \\ Jl. Kampus Bina Widya KM 12.5, Pekanbaru, Riau \\ widya.shintya7962@grad.unri.ac.id
}

\begin{abstract}
The application of online learning makes students get the experience difficulties in learning mathematics, especially in geometry material. The purpose of this study was to determine the difficulties experienced by students during online learning in seventh grade geometry material for SMP / MTs students. The research method used is descriptive method with a qualitative approach. The subjects of this study were 30 grade VII students. The data collection technique in this study was carried out by filling out a questionnaire that was provided using the application google form. The results obtained from this study were that the difficulties experienced by students in learning mathematics on geometry material when online learning took place were influenced by 2 factors, namely internal factors and external factors. Efforts that can be offered to overcome the difficulties experienced by these students can be in the form of, (a) the teacher can provide a fun learning method and can increase student interest in learning, (b) increase the number of practice questions related to the material being studied, and so on.
\end{abstract}

Keywords: Online learning, Student difficulty, Geometry

\begin{abstract}
Abstrak
Penerapan pembelajaran daring membuat siswa mengalami kesulitan dalam melakukan pembelajaran matematika terutama pada materi geometri. Tujuan dari penelitian ini adalah untuk mengetahui kesulitan yang dialami siswa selama pembelajaran daring berlangsung pada materi geometri kelas VII siswa SMP/MTs. Metode penelitian yang digunakan yaitu metode deskriptif dengan pendekatan kualitatif. Subjek dari penelitian ini adalah siswa kelas VII sebanyak 30 orang. Teknik pengumpulan data pada penelitian ini dilakukan dengan mengisi angket yang telah disediakan menggunakan aplikasi google form. Hasil yang diperoleh dari penelitian ini yaitu didapatkan bahwa kesulitan yang dialami siswa dalam pembelajaran matematika pada materi geometri saat pembelajaran daring berlangsung dipengaruhi oleh 2 faktor yaitu faktor internal dan faktor eksternal. Upaya yang dapat ditawarkan untuk mengatasi kesulitan yang dialami siswa ini dapat berupa, (a) guru dapat memberikan metode pembelajaran yang menyenangkan dan dapat menambah minat siswa dalam belajar, (b) memperbanyak latihan soal yang berkaitan dengan materi yang dipelajari, dan lain sebagainya.
\end{abstract}

Kata kunci: Pembelajaran daring, Kesulitan siswa, Geometri

Copyright (c) 2022 Widya Shintya Dewi, Maimunah, Yenita Roza

$\triangle$ Corresponding author: Maimunah

Email Address: maimunah@lecturer.unri.ac.id (Perum. Puri Alam Permai E7 Tuah Madani, Pekanbaru)

Received 07 May 2021, Accepted 07 September 2021, Published 05 February 2022

\section{PENDAHULUAN}

Tahun 2020 diawali dengan ditemukan suatu penyakit baru yang berkembang dari Provinsi Wuhan di Cina dan menyebar secara cepat ke seluruh penjuru dunia. Kejadian ini menimbulkan kepanikan publik yang berpengaruh pada kondisi ekonomi, sosial juga pendidikan. Dampak pada bidang pendidikan ini, membuat guru dan siswa menjadi kesulitan dalam melakukan pembelajaran. Pembelajaran yang biasanya dilakukan di sekolah secara tatap muka harus terhenti dan ini membuat guru dan perangkat sekolah melakukan inovasi agar siswa tetap dapat menerima pembelajaran. Salah satu langkah yang diambil adalah melakukan pembelajaran secara daring (dalam jaringan) melalui internet dengan menggunakan media teknologi. Keberadaan teknologi pada masa ini sangat 
diperlukan dan menjadikan pembelajaran daring menjadi satu-satunya solusi untuk mewujudkan tejadinya kegiatan pembelajaran (Alifia \& Pradipta; 2021).

Pembelajaran daring adalah pembelajaran yang dilakukan dalam jarak jauh dengan menggunakan bantuan internet dan media teknologi seperti handphone, laptop dan komputer (Fauzy \& Nurfauziah: 2021). Pembelajaran daring ini membutuhkan persiapan dan penyesuaian yang lebih banyak karena dilakukan mendadak dan terpaksa. Pembelajaran secara daring ini diterapkan pada semua mata pelajaran termasuk Matematika. Matematika merupakan mata pelajaran yang diajarkan disetiap tingkat pendidikan mulai dari Sekolah Dasar, Menengah hingga perguruan tinggi. Dimana matematika ini dapat digunakan dalam menganalisa dan menyederhanakan berbagai masalah dalam kehidupan sehari-hari (Jamal: 2014). Menurut Ruseffendi (2006) (Utami et al.: 2020) yang mengatakan bahwa "Matematika dianggap sebagai ilmu yang sukar, rumit dan memperdayakan". Ini sejalan dengan pendapat Krisdianto H., dkk (Hadiprasetyo et al.: 2020) dimana guru matematika menyebutkan bahwa kebanyakan siswa menganggap matematika adalah pelajaran yang susah dan matematika menjadi mata pelajaran yang tidak disukai oleh siswa. Hal ini, menyebabkan tingkat kesulitan siswa dalam belajar matematika menjadi lebih tinggi. Terutama saat diberlakukannya pembelajaran secara daring, dimana saat pembelajaran di sekolah, siswa dapat bertanya secara langsung kepada guru. Namun ketika pembelajaran daring, siswa menjadi kesulitan untuk bertanya dan terkadang tidak mendapatkan solusi yang jelas. Menurut Wachid Palguna (Sena: 2020) Siswa mengeluhkan pembelajaran berlangsung hanya dengan arahan oleh guru untuk membaca materi kemudian guru memberikan pertanyaan yang kemudian dikerjakan oleh siswa pada buku latihan dan dikumpulkan melalui Aplikasi Whatsapp atau Google Classroom. Pada penelitian yang dilakukan oleh Krisdianto H, dkk (Hadiprasetyo et al.: 2020) untuk melihat kesulitan yang dialami siswa dalam belajar matematika secara daring, didapatkan bahwa kesulitan belajar matematika siswa dengan pembelajaran daring ada pada kategori cukup dan tinggi yakni 7 siswa dengan tingkat kesulitan rendah dan 3 siswa dengan kategori tinggi. Berdasarkan hasil wawancara, juga didapatkan bahwa siswa tidak terlalu bersemangat dan lebih menyukai pembelajaran tatap muka. Disamping itu, koneksi internet juga menjadi penghambat siswa dalam pembelajaran secara daring.

Salah satu materi matematika yang dianggap sulit dimengerti oleh siswa adalah materi geometri. Berdasarkan hasil dari Pusat Penilaian Pendidikan dan Kementrian Pendidikan dan Kebudayaan (Kebudayaan: 2019) pada tahun 2019 didapatkan bahwa persentase siwa dalam menjawab soal geometri masih rendah dibandingkan materi aljabar dan statistika dan peluang yakni sebanyak 42,27\%. Menurut Abdussakir dan Junedi (Sari \& Roesdiana: 2019) Materi geometri adalah materi yang sulit untuk dimengerti dan dipahami oleh siswa. Hal ini disebabkan karena materi geometri dianggap sebagai materi yang abstrak dan membutuhkan penalaran. Menurut Nurhasanah et al, (2007), Geometri merupakan suatu materi yang berkaitan dengan pembentukan abstrak yang tidak dapat dilakukan dengan transfer perngetahuan dan ceramah melainkan melalui pembentukan konsep yang melewati berbagai rangkaian kegiatan langsung yang dilakukan oleh siswa (Fauzi \& 
Analisis Kesulitan Siswa dalam Pembelajaran Daring pada Materi Geometri Kelas VII SMP Kota Pekanbaru, Widya Shintya Dewi, Maimunah, Yenita Roza

Arisetyawan: 2020). Kebanyakan siswa dapat mengenal bentuk-bentuk dari bidang geometri yang dipelajari secara visual, namun pada tahap menganalisis, memahami hubungan antar materi geometri dan memecahkan masalah yang bersifat geometris siswa masih mengalami kesulitan. Menurut Abdurrahman Mulyono, 2003 kesulitan belajar pertama kali dikemukakan oleh the united states office of education (1977) dan terdiri dari: Kesulitan pada siswa, kesulitan pada guru, kesulitan dalam menguasai materi, kesulitan pada metode pembelajaran, kesulitan pada pendekatan dan strategi pembelajaran, kesulitan pada media dan kesulitan pada lingkungan (Mega: 2020). Kesulitan yang dialami siswa ini dapat dipengaruhi oleh beberapa faktor yang dapat berasal dari dalam (faktor internal) dan dari luar (faktor eksternal). Faktor internal merupakan faktor yang berasal dari diri siswa tersebut yang dapat berupa minat, motivasi, intelegensi, bakat, dan kesehatan dari siswa. Sedangkan faktor eksternal merupakan faktor yang berasal dari luar diri siswa tersebut, seperti lingkungan sekolah, keluarga ataupun masyarakat sekitar (Aryani: 2017). Berdasarkan penelitian yang dilakukan oleh Rika dan Lessa (Sari \& Roesdiana, 2019) Penguasaan materi geometri siswa masih rendah dan kurangnya antusias siswa dalam belajar geometri karena pembelajaran yang kurang menarik dan tidak adanya media/ bahan ajar yang digunakan untuk membantu dalam memahmi objek-objek geometri yang dipelajari.

Berdasarkan penelitian yang relevan di atas, maka peneliti berpedoman pada pemilihan sampel, teknik pengumpulan data, dan analisis pengolahan data. Penelitian ini dilakukan karena melihat banyaknya siswa yang mengalami kesulitan dalam pembelajaran terutama pada mata pelajaran matematika materi geometri. Pembelajaran geometri pada kelas VII ini mencakup materi garis dan sudut.

\section{METODE}

Jenis penelitian yang dilakukan adalah penelitan deskriptif. Penelitian ini mendeskripsikan analisis kesulitan belajar matematika siswa pada materi geometri pada saat pembelajaran daring berlangsung. Penelitian ini menggunakan pendekatan kualitatif. Penelitian ini dilakukan pada bulan April 2020. Subjek dalam penelitian ini adalah siswa kelas VII SMP N 40 Pekanbaru sebanyak 33 orang. Teknik pengumpulan data yang digunakan pada penelitian ini dilakukan dengan mengisi angket yang berisi pernyataan-pernyataan yang disediakan pada google form sebanyak 25 pernyataan yang diadaptasi dari Dyah Isnaini (Isnaini, 2020) yang kemudian disesuaikan dengan penelitian yang dilakukan. Angket yang digunakan menggunakan skala likert (Prof. Sukardi: 2019) yang memiliki 4 pilihan yaitu Sangat Setuju (SS), Setuju (S), Tidak Setuju (TS), dan Sangat Tidak Setuju (STS).

\section{HASIL DAN DISKUSI}

Pada penelitian ini, peneliti melakukan penyebaran angket secara daring melalui google form kepada siswa dalam mengumpulkan data mengenai kesulitan siswa SMP kelas VII dalam pembelajaran matematika pada materi Geometri. Penelitian ini dilakukan untuk mengetahui kesulitan 
apa saja yang dialami oleh siswa selama pembelajaran daring dilakukan pada materi pembelajaran Geometri. Pada penelitian ini kesulitan yang dialami siswa dibagi menjadi 3 indikator, yakni : (1) Kesulitan teknis, (2) Kesulitan saat pembelajaran berlangsung (faktor internal) dan (3) kesulitan yang berasal dari luar diri siswa (faktor eksternal).

\section{Kesulitan Teknis}

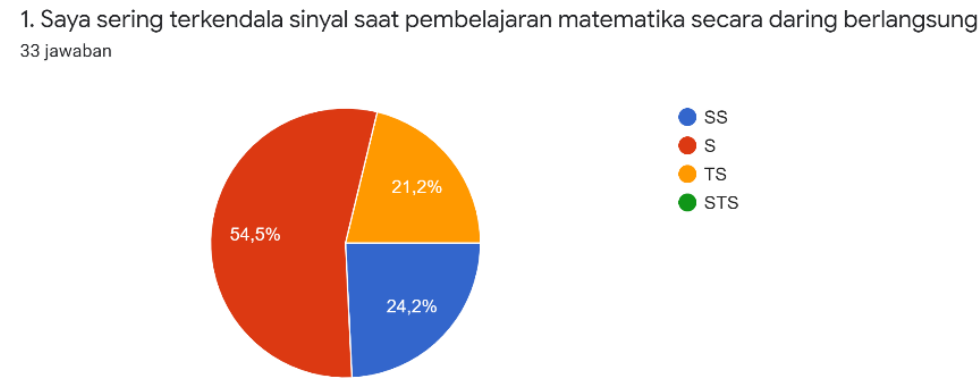

Diagram 1. Hasil Angket Kesulitan Teknis

Berdasarkan hasil angket yang didapatkan, kesulitan yang paling banyak dialami oleh siswa merupakan kendala lemahnya sinyal internet yang mereka gunakan pada saat pembelajaran daring berlangsung. Pada diagram 1 terlihat bahwa 24,2\% siswa memilih sangat setuju, 54,5\% siswa setuju dan $21,2 \%$ tidak setuju jika pembelajaran terkedala pada sinyal internet.

Berdasarkan hasil dari perolehan angket pada kesulitan teknis, maka dapat dikatakan bahwa kendala teknis yang terjadi pada siswa karena kendala sinyal sangat tinggi dan masih banyak siswa yang kesulitan untuk mengatasi kesulitan ini. Hal ini dapat dilihat dari persentase yang didapat dari siswa yang memilih tidak setuju yaitu sebesar $21.2 \%$ dan ini berada pada kategori kurang.

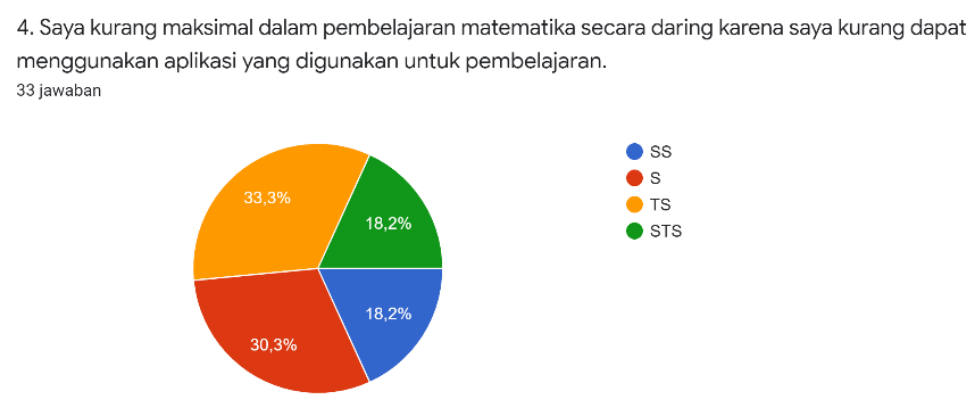

Diagram 2. Hasil Angket Kesulitan Teknis

Kesulitan teknis lainnya yang cukup banyak dialami oleh siswa adalah kendala dalam penggunaan aplikasi pembelajaran daring yang digunakan. Dimana pada diagram 2 diperoleh sebanyak 18,2\% siswa memilih sangat setuju dan 30,3\% siswa memilih setuju untuk pengunaan aplikasi yang sulit. Berdasarkan perolehan persentase tidak setuju dan sangat tidak setuju pada kendala teknis ini berada dalam kategori kurang dan sangat kurang. Dimana ini bearti bahwa siswa masih kesulitan dalam menggunakan aplikasi yang diterapkan pada pembelajaran daring. 
Analisis Kesulitan Siswa dalam Pembelajaran Daring pada Materi Geometri Kelas VII SMP Kota Pekanbaru, Widya Shintya Dewi, Maimunah, Yenita Roza

\section{Kesulitan saat pembelajaran berlangsung (Faktor Internal)}

14. Menurut saya pembelajaran matematika materi geometri secara daring sulit dan membosankan 33 jawaban

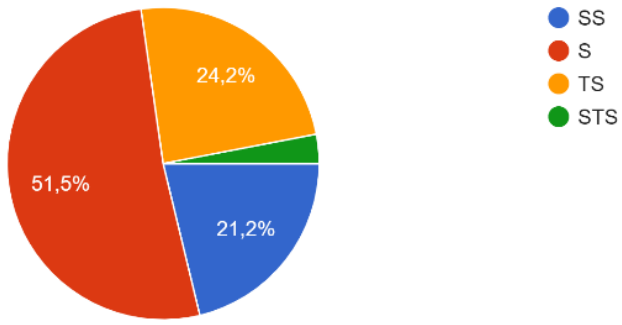

Diagram 3. Hasil Angket Kesulitan Saat Pembelajaran Berlangsung

Berdasarkan diagram 3, diperoleh hasil bahwa siswa menganggap pembelajaran pada materi geometri yang dilakukan secara daring sulit dan membosankan, dengan perolehan siswa yang memilih sangat setuju sebanyak $21,2 \%$ dan siswa yang memilih setuju sebanyak $51,5 \%$. Perolehan persentase siswa yang tidak setuju dan sangat tidak setuju yakni sebesar 24.2 dan 3,1 jika pembelajaran matematika pada materi geometri secara daring sulit dan membosankan, maka dapat dikatogerikan dalam kategori kurang dan kurang sekali.
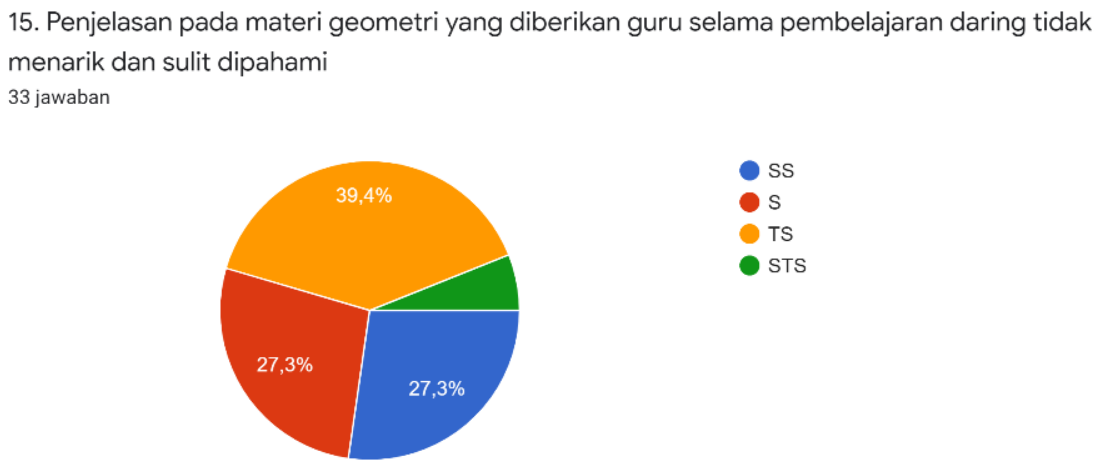

Diagram 4. Hasil Angket Kesulitan Saat Pembelajaran Berlangsung

Berdasarkan diagram yang diperoleh pada pernyataan ke 15, siswa beranggapan bahwa penjelasan dari guru pada materi geometri saat pembelajaran daring berlangsung tidak menarik dan sulit untuk dipahami. Hasil persentase sebesar 39.4\% dan 6\% pada siswa yang memilih tidak setuju dan sangat tidak setuju dan memiliki kategori kurang dan kurang sekali. 


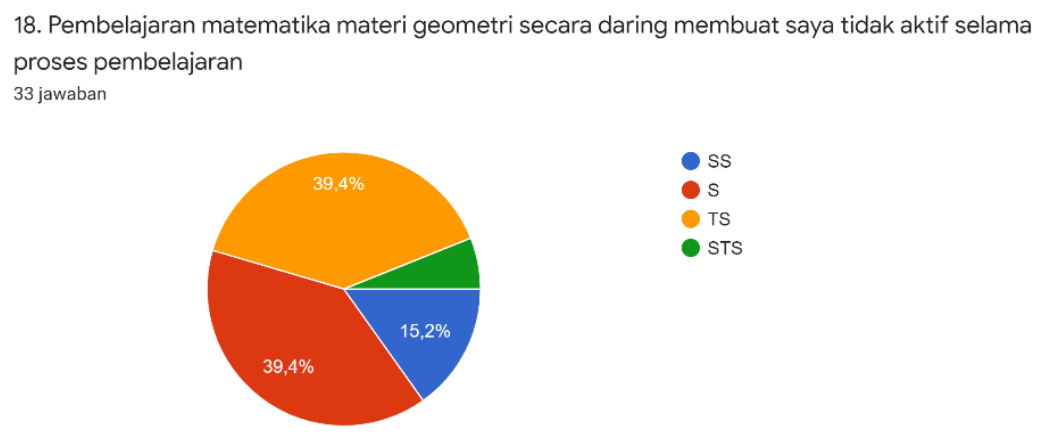

Diagram 5. Hasil Angket Kesulitan Saat Pembelajaran Berlangsung

Selain itu, pada pernyataan selanjutnya, juga didapatkan hasil bahwa pembelajaran geometri secara daring membuat siswa menjadi tidak aktif selama proses pembelajaran. Hasil yang diperoleh dapat dilihat dari diagram 2 dimana sebanyak 15,2\% siswa memilih sangat setuju dan 39,4\% memilih setuju. Hasil persentase pada kesulitan belajar yang menyatakan bahwa siswa tidak berperan aktif selama pembelajaran yakni sebesar $39.4 \%$ dan $6 \%$ dimana ini termasuk dalam kategori kurang dan kurang sekali.

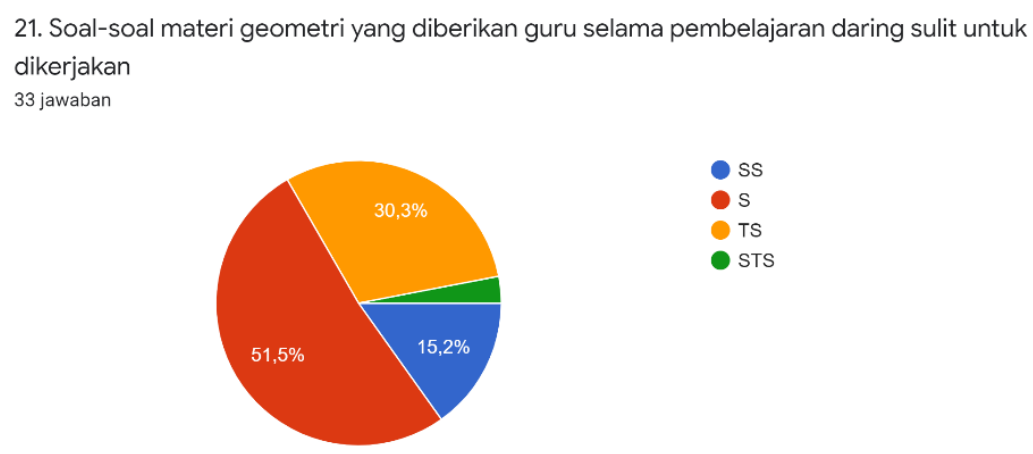

Diagram 6. Hasil Angket Kesulitan Saat Pembelajaran Berlangsung

Kesulitan lainnya yang didapatkan dari angket yaitu sulitnya soal geomteri yang diberikan guru selama pembelajaran daring berlangsung. Dimana sebanyak 15,2\% siswa memilih sangat setuju dan $51,5 \%$ memilih setuju pada pernyataan ini. Persentase yang didapatkan pada kesulitan yang dialami siswa dikarenakan soal-soal yang diberikan guru selama pembelajaran daring sulit dikerjakan dan siswa yang memilih tidak setuju dan sangat tidak setuju sebesar $15.2 \%$ dan $3 \%$ yang berada dalam kategori kurang sekali.

\section{Kesulitan yang berasal dari lingkungan (Faktor Eksternal)}

Berdasarkan hasil angket yang telah didapatkan, faktor eksternal yang berasal dari lingkungan sekitar siswa ini hanya mempengaruhi sebagian kecil dari siswa. Persentase yang didapatkan pada angket juga menunjukkan bahwa kesulitan yang dialami siswa pada faktor eksternal masih dalam kategori baik. Ini menandakan peran orang tua yang sudah baik dalam mendampingi/ memberi arahan 
kepada siswa ketika pembelajaran daring berlangsung. Selain itu guru sudah menampilkan media yang dapat membantu siswa dalam pembelajaran daring pada materi geometri dan sudah memberikan kesempatan kepada siswa untuk bertanya berkaitan dengan materi yang disampaikan.

\section{KESIMPULAN}

Berdasarkan hasil diskusi yang telah dipaparkan di atas, maka dapat disimpulkan bahwa kesulitan-kesulitan yang dihadapi oleh siswa pada materi geometri pada kelas VII SMP terbagi menjadi tiga kategori, yakni pertama adalah kesulitan secara teknis : (1) kesulitan karena terkendala oleh sinyal internet saat pembelajaran daring berlangsung, (2) masih banyaknya siswa yang kurang dapat menggunakan aplikasi yang digunakan dalam pembelajaran daring. Kedua, kesulitan saat pembelajaran berlangsung (faktor internal) : (1) Pembelajaran pada materi geometri yang membosankan dan sulit, (2) penjelasan pada materi geometri yang diberikan guru selama pembelajaran daring tidak menarik dan sulit dipahami (3) Pembelajaran daring membuat siswa tidak aktif selama pembelajaran daring berlangsung, (4) sulitnya memahami langkah-langkah kegiatan pembelajaran, serta (5) sulitnya soal-soal materi geometri yang diberikan guru selama pembelajaran berlangsung. Ketiga, kesulitan yang berasal dari luar diri siswa (faktor eksternal). Pada faktor ketiga, siswa sudah mendapatkan dukungan dari lingkungan siswa baik dari orang tua maupun guru.

\section{REFERENSI}

Alifia, Z., \& Pradipta, T. R. (2021). Analisis Motivasi Belajar Matematika Siswa dalam Penerapan Edmodo di Masa Pandemi COVID-19. Jurnal Cendekia: Jurnal Pendidikan Matematika, 5(2), 1062-1070. https://doi.org/10.31004/cendekia.v5i2.591

Aryani, F. (2017). Faktor-Faktor Penyebab Kesulitan Belajar dalam Mengikuti Mata Pelajaran Pembuatan Pola Siswa Kelas X SMK Muhammadiyah 1 Tempel. Skripsi, 1-109. file:///C:/Users/USER/Downloads/Skripsi_Farida Aryani_13513241038.pdf

Fauzi, I., \& Arisetyawan, A. (2020). Analisis Kesulitan Belajar Siswa pada Materi Geometri Di Sekolah Dasar. Kreano, Jurnal Matematika Kreatif-Inovatif, 11(1), 27-35. https://doi.org/10.15294/kreano.v11i1.20726

Fauzy, A., \& Nurfauziah, P. (2021). Kesulitan Pembelajaran Daring Matematika Pada Masa Pandemi COVID-19 di SMP Muslimin Cililin. Jurnal Cendekia: Jurnal Pendidikan Matematika, 5(1), 551-561. https://doi.org/10.31004/cendekia.v5i1.514

Hadiprasetyo, K., Exacta, A. P., \& Maharani, A. (2020). Matematika Dengan Pembelajaran Dalam Jaringan ( Daring) Selama Masa Darurat COVID-19 Pada Siswa Kelas VIII SMP Negeri 2 NGADIROJO TAHUN AJARAN 2019/2020. VI, 6-12.

ISNAINI, D. (2020). Kesulitan Siswa Kelas Vii Dalam Pembelajaran Matematika Berbasis Daring Di Smp Negeri 2 Tuntang Tahun Pelajaran 2019/2020. E-Repository.Perpus.Iainsalatiga.Ac .... http://e-repository.perpus.iainsalatiga.ac.id/9689/1/DYAH ISNAINI 23070160082-NASKAH 
JADI.pdf

Jamal, F. (2014). Analisis Kesulitan Belajar Siswa Dalam Mata Pelajaran Matematika Pada Materi Peluang Kelas XI IPA SMA Muhammadiyah Meulaboh Johan Pahlawan. Jurnal MAJU (Jurnal $\begin{array}{llll}\text { Pendidikan } & \text { Matematika), } & 18-36 .\end{array}$ http://www.ejournal.stkipbbm.ac.id/index.php/mtk/article/view/232

Kebudayaan, P. P. P. dan K. P. dan. (2019). Laporan Hasil Ujian Nasional. Https://Hasilun.Puspendik.Kemdikbud.Go.Id. https://hasilun.puspendik.kemdikbud.go.id Mega, L. (2020). Analisis Kesulitan Belajar Matematika Siswa Pada Pokok Bahasana Geometri Kubus dan Balok Di Sekolah Menengah Pertama Negeri 26 Sarolangun.

Prof. Sukardi, P. . (2019). Metodologi Penelitian Pendidikan. In Bumi Aksara.

Sari, R. M. M., \& Roesdiana, L. (2019). Analisis kesulitan belajar siswa SMA pada pembelajaran geometri. AKSIOMA: Jurnal Matematika Dan Pendidikan Matematika, 10(2), 209-214. https://doi.org/10.26877/aks.v10i2.4253

Sena, W. P. B. (2020). Analisis Kesulitan Siswa Dalam Pembelajaran Daring Materi Statistika Mata Pelajaran Matematika Pada Mts Negeri Di Grobogan (Program Studi Tadris Matematika Fakultas Tarbiyah Dan Ilmu Keguruan Institut Agama Islam Negeri Salatiga 2020). 